\section{Sub-cellular Distribution of Serotonin in the Developing Rat Brain}

IT is well known that the neonatal rat brain contains relatively little serotonin ${ }^{1,2}$ and that the level of this amine increases slowly with age. Karki et al. ${ }^{3}$ have shown that the onzymes mediating the synthesis and oxidation of serotonin are also low in the immature rat brain, and increase thereafter with growth of the animal. The aforomentioned authors suggest that the low levels of indolamines in the rat brain at birth can be attributed to a deficiency of the binding or storage system, and are not a reflexion of the insufficiency of the enzyme systems. Schanberg and Giarman ${ }^{4,5}$ have shown that endogenous brain serotonin distributes itself between the particulate matter of brain homogenates and the supernatants, and that this rolationship is suscoptible to altoration by drugs. It was, therefore, of interest to investigate the subcellular distribution of serotonin in the developing rat brain and to determino whothor it will parallol other maturational changes.

Rats of the Wistar strain, bred in our colony under standard conditions of management and nutrition, were used in this investigation, and were selected at various ages after birth. Animals were decapitated rapidly, the brains minus cerebella removed, weighed and homogenized in unbuffered $0.3 \mathrm{M}$ sucrose containing tranyleypramine (1 umole). All procedures were carried out at $4^{\circ} \mathrm{C}$. Sufficiont brains were pooled to give a homogenate dilution of 20 per cont $(\mathrm{w} / \mathrm{v})$. Duplicate aliquots of tho homogenntes were centrifuged for $30 \mathrm{~min}$ in a No. 40 rotor of the model $L$ Spinco ultracentrifuge. The high-spoed residuo and supernatant were extracted separately for their scrotonin content by the method of Shore and Olin", as modified by Mead and Finger ${ }^{7}$ and assayed in concentrated hydrochloric acid as described by Bogdanski et al. ${ }^{8}$. All results are averages of six or more individual determinations, and represent 10-30 animals, depending on the age group.

Table 1. Wet Weights AND Serotonin Context of the Developina Table 1. WhT WETGHA

\begin{tabular}{|c|c|c|c|c|c|c|}
\hline $\begin{array}{c}\text { Age } \\
\text { (days) }\end{array}$ & $\begin{array}{c}\text { Brain wet } \\
\text { wcight- } \\
\text { cerebellum } \\
\text { (g) }\end{array}$ & $\begin{array}{l}\text { Percentage } \\
\text { of adult } \\
\text { brain wet } \\
\text { weight- } \\
\text { cerebellum }\end{array}$ & $\underset{(\gamma / g)}{5-\mathrm{HT}}$ & $\begin{array}{l}\text { Brain 5-HT } \\
\gamma / \mathrm{gm} \text { as per cent } \\
\text { of adult levels }\end{array}$ & $\begin{array}{l}\text { Percentage } \\
\text { of total } \\
5 \cdot \text { HT in } \\
\text { residue }\end{array}$ & $\begin{array}{c}\text { Ratio } \\
\text { brain wt. } \\
5-H T \\
\text { content }\end{array}$ \\
\hline & 0.26 & $17 \cdot 1$ & 0.26 & $39 \cdot 3$ & $72 \cdot 4$ & $1 \cdot 0$ \\
\hline 2 & 0.26 & $17 \cdot 2$ & 0.27 & $41 \cdot 6$ & 72 & 1.05 \\
\hline 4 & 0.43 & $28 \cdot \overline{6}$ & $0 . \overline{3}$ & $47 \cdot 3$ & 73 & 1.4 \\
\hline 10 & 0.08 & $45 \cdot 5$ & 0.3 & $46 \cdot 4$ & & 2 . \\
\hline 12 & 0.85 & 56. & 0.3 & 55 & & 2 \\
\hline 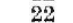 & 1.03 & 68 & 0.3 & 56 & & 2 \\
\hline & $1 \cdot 13$ & 75 & 0. & 78. & & \\
\hline & 1.3 & 88 & 0.5 & 78.9 & & $\overline{2} \cdot 5$ \\
\hline Adu & 1.5 & - & 0.65 & - & 74 & $2 \cdot 3$ \\
\hline
\end{tabular}

The weight of brains and the amine content of rat brains at various stages of development (Table 1) were obtained without the corobollum. It is apparent that the rat brain at one day of age contains 39 per cent of the adult amine content, but only 17 per cent of the adult weight. Tho values for 5-HT contont in the developing brain are in agreement with those quoted by Karki et al. ${ }^{3}$. At 1 day post-natally, tho ratio of brain weight to serotonin is unity, and inereases to $2 \cdot 3$ by 10 days. Thoreafter, this ratio is approximately constant, suggesting that both wet weight and sorotonin-levels are maturing at equal rates.

A number of investigators ${ }^{4,9}$ have consistently observed that the bulk of endogenous brain serotonin ( 75 per cent) is associnted with the high-speed residue. Our results show that homogenates prepared from rat brains at all ages from I day post-natally yiold essentinlly an adult subcollular distribution, in that in excess of 70 per cent is recovered in the particulate frastion. The concentration of a number of enzymes, such as suceinic dehydrogennse ${ }^{10}$, cholinesterase ${ }^{11}$, and glutamic acid decarboxylase ${ }^{12,13}$, is low in the immature rat brain and increases slowly to adult levels. Typical adult electrical aotivity can only be rocordod from the rat cortex at 2 weeks of age ${ }^{14}$, and it has been suggested that mature bioelectric activity depends on completion of synaptic connoxions in the cortex ${ }^{15,16}$.
The suggestion has been made by $\mathrm{Karki}^{3}$ that the immature rat brain cannot bind serotonin es efficiently as it does at maturity, and a similar phenomenon has been observed by Glowinski et al. ${ }^{17}$ for the binding of circulating norepinephrine by the developing heart. Though the immature brain may bo deficient in its ability to store sorotonin, such differences are not evident in the present results on the sub-cellular distribution. It can only be suggested that if specific cellular components are responsiblo for the binding of small quantities of endogenous amine, then these components do not exhibit maturational changes which are qualitative in nature. It is tompting to speculate that the in vivo binding of serotonin might correlate with the maturation of synaptio vesicles, and also possibly to the biosynthesis of gangliosides. Possibly the cellular components responsible for the binding of serotonin are present at birth in the rat brain and mature at the same rates as the wet weight, and the total amine storago capacity, thus resulting in an essentially constant sub-cellular distribution.

We thank Dr. Williamina A. Himwich for her advice in the preparation of this paper.

\section{B. HABER *}

A. Kamano

Thudichum Psychiatric Research Laboratory, Galesburg State Research Hospital, Galesburg, Tllinois.

* Present address: Department of Biochemistry, City of Hope Medical Center, Duarte, California.

${ }^{1}$ Karki, N., Kuntzman, R., and Brodie, B. B., Fed. Proc., 19, 282 (1960). ${ }^{2}$ Nachmias, V., J. Neurochem., 6, 99 (1960).

${ }^{3}$ Karki, N., Kuntzman, R., and Brodic, B. B., J. Neurochem., 9, 53 (1962).

* Giarman, N. J., and Schanberg. S. M., Biochem. Pharmacol, 301 (1958).

¿ Schanberg, S. M., and Giarman, N. J., Biochem. Pharmacol., 11, 187 (1962). - Shore, P. A., and Olin, I. S., J. Pharmacol. Exp. Therap., 122, 295 (1958). 'Mead, J. A. R., and Finger, K. F., Biochern. Pharmacol., 6, 52 (1961).

${ }^{3}$ Bogdanski, B. F., Pletcher, A., Brodie, B. B., and Udenfriend, S., $J$. Pharmacol., 117,', 82 (1956).

${ }^{\circ} G$ Green, H., and Sawyer, J. I., Arch. Intern. Pharmacodyn.,135, 426 (1962).

${ }^{10}$ Potter, V. R., Schncider, W. C., and Liehl, G. J., Cancer Research, 5, 21 (1.945).

${ }^{11}$ Nachmansohn, P., Yale J. Biol. Med., 12, 565 (1940).

${ }^{13}$ Graves, J., and Himwich, W. A., Physiologist, 2, 48 (1959).

${ }^{13}$ Himwich, W. A,, Petersen, J. C., and Graves, J., Rec. Adv. Biol. Psychiat., 3, 218 (1961).

${ }^{14}$ Crain, S. M. Proc. Soc. Exp. Biol. and Med, 81, 49 (1952).

${ }^{15}$ Schade, J. P., J. Neurophysiol., 22, 245 (1959).

${ }^{19}$ Nobeck, C. R., and Purpura, D. Y., J. Comp. Neurol.,117, 291 (1961).

' Glowinski, J., Axelrod, A., Kopin, I. J., and Wurtman, R. J., J. Pharmacol. Exp. Therap., 146, 48 (1964)

\section{Oscillation in Enzyme Reactions}

THE widespread existence of periodic phenomena in living organisms is well known. These events, like all other matcrial phenomena in living systems, should ultimately be considered in terms of the individual chemical reactions occurring during the life process. Since chemical reactions occurring in biological systems are catalysed by enzymes, it was the purpose of our investigation to examine the possibility of oscillatory behaviour in cnzymc-catalysed reactions.

The mathematical treatment of the differential equations arising in chemical kinetic problems is often impeded by the fact that the exact analytic solution of the equations is difficult, if not impossible, to obtain. Nevertheless, Lotka ${ }^{1}$ in 1910 proposed an autocatalytic system wherein periodicity is clearly possible, and in $1921 \mathrm{Bray}^{2}$ illustrated experimentally a chemical system wherein poriodicity is actually observed.

Difficultios attending the mathematical treatment of the differential equations arising in enzyme kinetic problems have served as a severe impedance to the developmont of mzyme kinetic theory. However, Christiansen ${ }^{3}$ and Ozawa ${ }^{4}$ obtained analytical results indicating that oscillations could occur in certain types of enzymecatalysed reactions, provided certain conditions are met. Sinec then, Anderson ${ }^{5}$, Chance ${ }^{6}$ and Shnoll ${ }^{7}$ have 